\title{
Analisis Efektivitas Dan Kontribusi Pajak Reklame Dan Pajak Restoran Terhadap Pendapatan Asli Daerah Kota Bogor
}

\author{
Eka Yunita dan Yuliandi
kuntansi, Institut Bisnis dan Informatika Kesatuan \\ Eka Yunita dan Yuliandi
Program Studi Akuntansi, Institut Bisnis dan Informatika Kesatuan \\ E-Mail: yuliandi.kesatuan@gmail.com
}

Restaurant Tax, Advertising Tax \&

Regional Revenue

\section{ABSTRACT}

Local Revenue is a source of original revenue derived from the potential of the region it self. Local Revenue is often used as an indicator of a region's progress. If the original income of a region is high, the economy of the area is considered advanced. The higher the Local Revenue received, the less dependency between the Regional Government on the Central Government. The largest revenue potential for Local Revenue is generated from local tax collection. One of the potential local tax revenues in Bogor City is the advertisement tax and restaurant tax. The purpose of this study was to determine the level of effectiveness and contribution of advertisement tax and restaurant tax to Local Revenue in Bogor City and to find out the efforts made by the Bogor City Regional Revenue Agency in increasing its local tax revenue. The research method used is descriptive qualitative method. The result of this research is that the effectiveness of the advertisement tax and restaurant tax collection in Bogor City has been very effective, proven by the average advertisement tax effectiveness ratio of $104.06 \%$ and restaurant tax of $103.93 \%$. The contribution of advertisement tax and restaurant tax to Local Revenue in Bogor City is still not good, as evidenced by the average advertisement tax contribution ratio of $1.43 \%$ including very poor criteria, and the average restaurant tax contribution of 12.99 . \% is in the poor criteria. Efforts made by the Bogor City Regional Revenue Agency in increasing advertisement tax revenue and restaurant tax are by collecting taxpayer data, checking tax rates, monitoring tax administration, and building communication and establishing closeness with the community.

Keywords: effectiveness, contribution, advertising tax, restaurant tax, local revenue

\begin{abstract}
ABSTRAK
Pendapatan Asli Daerah merupakan sumber pendapatan yang asli berasal dari potensi daerah itu sendiri. Pendapatan Asli Daerah seringkali dijadikan sebagai indikator atas kemajuan suatu daerah. Apabila pendapatan asli suatu daerah tinggi maka perekonomian daerah tersebut sudah dianggap maju. Semakin tinggi Pendapatan Asli Daerah yang diterima maka semakin berkurang tingkat ketergantungan antara Pemerintah Daerah terhadap Pemerintah Pusat. Potensi pendapatan terbesar Pendapatan Asli Darah yaitu dihasilkan dari pemungutan pajak daerah. Salah satu pendapatan pajak daerah yang sangat berpotensial di Kota Bogor adalah pajak reklame dan pajak restoran. Tujuan dari penelitian ini adalah untuk mengetahui tingkat efektivitas dan kontribusi pajak reklame dan pajak restoran terhadap Pendapatan Asli Daerah di Kota Bogor serta untuk mengatahui upaya yang dilakukan oleh Badan Pendapatan Daerah Kota Bogor dalam meningkatkan pendapatan pajak daerahnya. Metode penelitian yang digunakan adalah metode deskriptif kualitatif. Hasil dari penelitian ini adalah efektivitas dari pemungutan pajak reklame dan pajak restoran di Kota Bogor sudah sangat efektif terbukti dengan angka rata-rata rasio efektivitas pajak reklame sebesar 104,06\% dan pajak restoran sebesar 103,93\%. Kontribusi pajak reklame dan pajak restoran terhadap Pendapatan Asli Daerah di Kota Bogor masih belum dapat dikatakan baik, dibuktikan dengan angka rata-rata rasio kontribusi pajak reklame sebesar
\end{abstract}

JIAKES

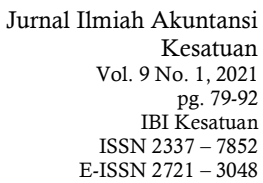


Restaurant Tax, Advertising Tax \& Regional Revenue

$1,43 \%$ termasuk kriteria sangat kurang, dan rata-rata kontribusi pajak restoran sebesar $12,99 \%$ termasuk kedalam kriteria kurang. Upaya yang dilakukan oleh Badan Pendapatan Daerah Kota Bogor dalam meningkatkan pendapatan pajak reklame dan pajak restoran adalah dengan melakukan pendataan wajib pajak, pemeriksaan tarif pajak, pengawasan penyelenggaraan pajak, dan membangun komunikasi dan menjalin kedekatan dengan masyarakat.

Kata kunci : efektivitas, kontribusi, pajak reklame, pajak restoran, pendapatan asli daerah

\section{0}

\section{PENDAHULUAN}

Negara Indonesia terdiri atas puluhan provinsi dan ratusan kabupaten kota, yang mana masing-masing daerah memiliki hak, wewenang dan kewajiban untuk mengurus sendiri urusan pemerintahan dan kepentingan masyarakat sesuai dengan peraturan perundang-undangan yang telah diatur dalam Undang-Undang Nomor 31 Tahun 2004 tentang Otonomi Daerah. Adapun manfaat dari Otonomi Daerah adalah meningkatkan pelayanan kepada masyarakat, mengembangkan ekonomi daerah dan pemerataan pembangunan (Peraturan perundang-undangan otonomi daerah, 2004). Untuk meningkatkan pelayanan kepada masyarakat serta meningkatkan pertumbuhan ekonomi dan pembangunan diperlukan penyediaan sumber- sumber Pendapatan Asli Daerah (PAD). Menurut (Handayani, 2019) Pendapatan Asli Daerah yaitu penerimaan yang diperoleh daerah dari sumber-sumber dalam wilayahnya sendiri yang dipungut berdasarkan Peraturan Daerah sesuai dengan peraturan Undang-Undang Nomor 33 Tahun 2004. Dengan demikian Pendapatan Asli Daerah merupakan sumber pendapatan yang asli berasal dari potensi daerah dimana Pemerintah daerah tersebut dapat menggali sumber Pendapatan Asli Daerah secara optimal. Sumber Pendapatan Asli Daerah terdiri dari (1) Pajak Daerah; (2) Hasil Retribusi Daerah; (3) Hasil Pengelolaan Kekayaan Daerah yang Dipisahkan; (4) Lain-lain Pendapatan Asli Daerah yang sah.

Pendapatan Asli Daerah seringkali dijadikan sebagai indikator atas kemajuan suatu daerah. Apabila pendapatan asli suatu daerah tinggi maka bisa dikatakan bahwa daerah tersebut sudah dianggap maju. Semakin tinggi Pendapatan Asli Daerah yang diterima maka semakin berkurang tingkat ketergantungan antara Pemerintah Daerah terhadap Pemerintah Pusat. Salah satu Pendapatan Asli Daerah yaitu dihasilkan dari pemungutan pajak. Di Indonesia ada banyak jenis pemungutan pajak, salah satunya pada lembaga pemungutan pajak dibagi menjadi dua golongan yakni Pajak Pusat dan Pajak Daerah. Pajak pusat digunakan untuk membiayai rumah tangga Negara sedangkan Pajak Daerah digunakan untuk membiayai rumah tangga daerah.

Dalam undang-undang Pajak Daerah dan Retribusi Daerah Nomor 18 Tahun 2009 (Undang-undang Pajak Daerah dan Retribusi Daerah, 2009), Pajak Daerah adalah kontribusi wajib kepada daerah yang terutang oleh orang pribadi atau badan yang bersifat memaksa berdasarkan undang-undang dengan tidak mendapatkan imbalan secara langsung dan digunakan untuk keperluan daerah bagi sebesar-besarnya kemakmuran rakyat. Pajak yang diberikan oleh penduduk kepada pemerintah daerah, ini akan digunakan untuk kepentingan pemerintahan dan kepentingan umum suatu daerah itu sendiri. Seperti pembangunan jembatan, jalan, penataan taman kota, pembukaan lapangan pekerjaan baru, dan kepentingan pembangunan serta pemerintahan lainnya. Selain untuk pembangunan suatu daerah, penerimaan pajak daerah juga merupakan salah satu sumber Anggaran Pendapatan Daerah (APBD) yang digunakan pemerintah dalam menjalankan program-program kerjanya. Berikut Pajak Daerah yang di terima pemerintah dibagi atas 2 bagian, yaitu: (1) Pajak Propinsi, yang terdiri dari Pajak Kendaraan Bermotor, Pajak Kendaraan diatas Air, Pajak Bea Balik Nama Kendaraan Bermotor (BBNKB), Pajak Bahan Bakar Kendaraan Bermotor (PBB-KB), Pajak Pengambilan dan Pemanfaatan Air Bawah Tanah, dan Pajak Rokok. (2) Pajak 
Kabupaten/kota, yang terdiri dari Pajak Hotel, Pajak Restoran, Pajak Hiburan, Pajak Reklame, Pajak Penerangan Jalan, Pajak Mineral Bukan Logam dan Batuan, Pajak Parkir, Pajak Air Tanah, Pajak Sarang Burung Walet, Pajak Bumi dan Bangunan Perdesaan dan Perkantoran dan Pajak Perolehan Hak Atas Tanah dan /atau Bangunan.

Dari semua jenis Pajak Daerah pajak reklame dan pajak restoran dianggap cukup potensial dalam menyumbang Pendapatan Asli Daerah di Kota Bogor. Dimana kedua pajak tersebut dianggap saling berkaitan. Reklame adalah benda, alat, perbuatan, atau media yang bentuk dan corak ragamnya dirancang untuk tujuan komersial memperkenalkan, menganjurkan, mempromosikan, atau untuk menarik perhatian umum terhadap barang, jasa, orang atau badan, yang dapat dilihat, dibaca, didengar, dirasakan, dan/atau dinikmati oleh umum. Sedangkan Pajak Reklame yaitu pajak atas penyelenggaraan reklame (Undang-undang Pajak Daerah dan Retribusi Daerah, 2009). Pajak Restoran adalah pajak atas pelayanan restoran, Restoran adalah fasilitas penyedia makanan dan/atau minuman dengan dipungut bayaran, yang mencakup juga rumah makan, kafetaria, kantin, warung, bar, dan sejenisnya termasuk jasa boga dan catering (Peraturan Daerah Kota Bogor, 2011).

Sebagai salah satu kota penyangga Ibu Kota DKI Jakarta, Bogor merupakan kota yang pertumbuhan dan perkembangan perekonomiannya bisa dikatakan relatif cepat. Hal ini bisa dilihat dari perkembangan perekonomian di kota Bogor dari berbagai sektor khususnya di sektor perdagangan tumbuh begitu pesat. Jika dipantau dari segi perdagangan dapat dilihat semakin maraknya restoran, rumah makan, cafe, coffee shop dan tempat makan lainnya yang baru didirikan di kota Bogor. Dengan melihat perkembangan ini maka penerimaan PAD dari sektor pajak reklame dan pajak restoran tentunya memiliki potensi yang cukup besar. Karena setiap perusahaan ataupun perorangan akan semakin banyak menggunakan media reklame untuk memperkenalkan berbagai jenis kegiatan usaha dan produk mereka kepada konsumen, begitu juga dengan para pengusaha penyedia tempat makanan/minuman seperti restoran, rumah makan dan cafe tentu akan dikenakan pungutan pajak pada tempat usahanya. Hal ini dapat dilihat dari sudut-sudut kota Bogor baik di pusat kota maupun pinggiran kota banyak terpampang berbagai macam bentuk reklame beserta tempat usaha mereka.

Untuk mengetahui lebih jelas mengenai pertumbuhan target dan realisasi Pajak Reklame, Pajak Restoran dan Pendapatan Asli Daerah (PAD) kota Bogor pada tahun 2010 sampai dengan tahun 2014 selama lima tahun dapat dilihat dari tabel berikut:

Tabel 1. Target dan Realisasi Pajak Reklame Kota Bogor tahun2010-2014

\begin{tabular}{|c|c|c|}
\hline Tahun & Target Pajak Reklame $(\mathrm{Rp})$ & Realisasi Pajak Reklame $(\mathrm{Rp})$ \\
\hline 2010 & 7.814 .400 .000 & 8.015 .331 .887 \\
\hline 2011 & 9.500 .000 .000 & 9.924 .574 .509 \\
\hline 2012 & 9.500 .000 .000 & 10.045 .280 .964 \\
\hline 2013 & 11.778 .862 .000 & 12.276 .398 .478 \\
\hline 2014 & 13.673 .865 .000 & 13.842 .141 .787 \\
\hline
\end{tabular}

Sumber: (http://www.djpk.kemenkeu.go.id)

Target penerimaan pajak reklame dari tahun 2010 sampai dengan tahun 2014 mengalami peningkatan. Tahun 2012 mengalami realisasi pajak reklame yang paling tinggi yaitu sebesar Rp 545.280.964 dari nilai target. Pada tahun 2014 mengalami realisasi pajak reklame yang paling rendah yaitu sebesar Rp 168.276.787 dari nilai target, akan tetapi untuk nilai target penerimaan pajak reklame pada tahun 2014 paling besar dibandingkan tahun-tahun sebelumnya. Dari data tabel diatas terlihat jelas bahwa pajak reklame sangat potensial sehingga setiap tahun mengalamai peningkatan target pajak. Peningkatan pajak reklame tidak lepas dari masyarakat modern yang semakin melek akan dunia usaha yang kian menjanjikan nilai omsetnya. Dimana dalam mempromosikan jenis produk/usahanya memerlukan media promosi yaitu reklame.

Jika dibandingkan dengan pendapatan pajak reklame yang setiap tahunnya mengalami peningkatan, pajak restoran pun sama setiap tahunnya mengalami peningkatan bahkan dari sisi nilai target dan realisasi pajaknya lebih besar dibandingkan
Restaurant Tax, Advertising Tax \& Regional Revenue 
Restaurant Tax, Advertising Tax \& Regional Revenue

\section{2}

pajak reklame. Dapat dilihat dari tabel 1.2 nilai target dan realisasi pajak restoran dari tahun 2010-2014 secara signifikan terus mengalami peningkatan. Ini menandakan bahwa masyarakat di kota bogor memiliki jiwa konsumtif yang cukup tinggi. Hal ini disebabkan karena masyarakat beranggapan bahwa dengan membeli makanan/minuman cepat saji lebih efisien dalam menghemat waktu, selain itu dengan mengkonsumsi makanan cepat saji mereka dianggap lebih berkelas dan modern. Dengan adanya hal tersebut, menyebabkan pengusaha makanan/minuman saling bersaing untuk menciptakan suatu inovasi makanan/minuman yang menarik dan sesuai untuk selera masyarakat. Maka tidak dipungkiri, banyaknya pelaku usaha di bidang makanan dan minuman ikut serta meningkatkan jumlah tempat makan seperti, restoran, rumah makan, maupun cafe.

Tabel 2 Target dan Realisasi Pajak Restoran Kota Bogor tahun 2010-2014

\begin{tabular}{|c|c|c|}
\hline Tahun & Target Pajak Restoran (Rp) & Realisasi Pajak Restoran (Rp) \\
\hline 2010 & 15.850 .000 .000 & 23.342 .416 .373 \\
\hline 2011 & 23.000 .000 .000 & 27.252 .802 .195 \\
\hline 2012 & 26.465 .000 .000 & 39.510 .789 .644 \\
\hline 2013 & 34.850 .000 .000 & 50.035 .057 .749 \\
\hline 2014 & 44.600 .000 .000 & 59.965 .768 .360 \\
\hline
\end{tabular}

Sumber: (http://www.djpk.kemenkeu.go.id)

Tabel 3 Target dan Realisasi PAD Kota Bogor tahun 2010-2014

\begin{tabular}{|c|c|c|}
\hline Tahun & Target PAD $(\mathrm{Rp})$ & Realisasi PAD $(\mathrm{Rp})$ \\
\hline 2010 & 112.203 .927 .506 & 127.488 .089 .831 \\
\hline 2011 & 181.953 .035 .493 & 230.449 .644 .620 \\
\hline 2012 & 211.014 .043 .190 & 300.932 .470 .210 \\
\hline 2013 & 315.010 .039 .863 & 464.695 .880 .485 \\
\hline 2014 & 413.249 .212 .694 & 544.835 .708 .254 \\
\hline
\end{tabular}

Sumber: (http://www.djpk.kemenkeu.go.id)

Pada tabel 1.3 menujukan bahwa target pendapatan asli daerah mengalami peningkatan secara signifikan setiap tahun dan nilai realisasinya selalu melebihi nilai target. Peningkatan nilai target PAD tidak lain didukung oleh peningkatan pendapatan pajak daerah. Namun selain berpotensi mendapatkan pendapatan yang cukup besar bagi pendapatan asli daerah, pajak reklame dan restoran tidak lepas dari masalahmasalah umum yang menghambat efektivitas dan kontribusinya bagi pendapatan asli daerah. Masalah umum yang dihadapi pada sektor pajak reklame adalah masih adanya reklame yang terpasang tanpa ijin pemasangan dari pemerintah kota ataupun reklame yang perijinannya sudah mati, reklame illegal, reklame terpasang tidak sesuai titik dan standar keamanan dan reklame yang tidak membayar pajak. Masalah umum ini apabila dibiarkan akan berdampak pada tingkat efektivitas dan kontribusi pendapatan pajak reklame terhadap pendapatan asli daerah dan juga tata ruang publik. Maka dalam hal ini diperlukan peran pentingnya ketegasan pemerintah dalam melakukan penertiban dan pengawasan reklame serta kesadaran para penyelenggara reklame dalam meningkatkan pendapatan pajak.

Sedangkan masalah umum dalam sektor pajak restoran berdasarkan (https://www.suaramerdeka.com/, 2019) adalah permasalahan mendasar yang ditemui dalam pemungutan pajak restoran yang paling utama adalah beban pajak yang terkadang masih ditanggung oleh pengusaha. Padahal subjek Pajak Restoran adalah orang pribadi atau badan yang membeli makanan dan/atau minuman di restoran. Dalam pengertian lain, Pajak Restoran menjadi beban konsumen yang berbelanja di restoran. Restoran ini mencakup rumah makan, kafetaria, kantin, warung, bar, dan sejenisnya, termasuk jasa boga/katering. Peran pengusaha sebenarnya selaku wajib pungut yang bertugas mengumpulkan pajak dari konsumen dan menyetorkannya ke kas daerah. Dengan beban pajak masih ditanggung oleh pengusaha, diyakini jumlah yang bisa disetor tidak akan banyak. Permasalahan kedua, data laporan WPPajak Restoran yang tidak riil dan jauh di bawah kondisi sebenarnya. Padahal Pajak Restoran tergolong 
ke dalam jenis self assessment system, yakni wajib pajak diberi kepercayaan untuk menghitung, membayar, dan melaporkan sendiri jumlah pajak yang seharusnya terutang. Implikasi dari sistem ini, wewenang untuk menetapkan besarnya pajak yang terutang ada pada WP sendiri, wajib pajak aktif dari menghitung, memperhitungkan, menyetorkan, dan melaporkan sendiri pajak yang terutang, fiskus tidak ikut campur dan hanya mengawasi. Karena karakteristik inilah terkadang WP menyalahgunakan wewenang. Mereka tidak melaporkan pajak riil yang dipungut. Laporan cenderung di bawah kondisi riil yang sebenarnya. Permasalahan selanjutnya adalah sistem pembukuan di restoran yang tidak tertib dan tidak baik.

Masalah-masalah umum ini perlu dilakukan strategi yang tepat agar pemungutan pajak restoran dapat dilakukan secara optimal. Pertama, perlu ketersediaan data potensi Pajak Restoran secara valid. Dari jumlah hari kerja di restoran, jumlah meja kursi yang tersedia, tarif, sampai kisaran jumlah pengunjung, dan data detail lain. Data ini akan menentukan besar pajak daerah yang dapat dipungut sehingga dapat diketahui besar target penerimaan pada suatu periode. Kedua, mengefektifkan sistem pelaporan melalui e-tax sebagai konskuensi sistem self assessment. Prinsipnya, wajib pajak harus dimudahkan dalam melak8ukan pelaporan pajak terutang dengan tidak memerlukan proses yang rumit. Ketiga, mengefektifkan proses penagihan. Keempat, pemantauan aktivitas perpajakan wajib pajak. Kelima, pemasangan tapping box. Langkah ini juga dalam rangka mengetahui omzet riil restoran. Tapping box adalah alat penangkap transaksi yang tercetak oleh printer point of sales yang ditempatkan di antara cash register atau CPU dan printer. Fungsinya mencatat setiap transaksi wajib pajak sebagai dasar penghitungan pajak dan keenam, pemeriksaan pajak, hal ini dimungkinkan jika terlihat indikasi laporan wajib pajak tidak riil. Untuk mengoptimalkan/meningkatkan pemungutan pajak reklame dan pajak restoran maka perlu dilakukan strategi-strategi dan perhitungan penerimaan pajak daerah yang akurat sehingga diketahui besaran tingkat efektivitas dan tingkat kontribusinya terhadap Penerimaan Asli Daerah (PAD).

Berikut penelitian terdahulu yang peneliti gunakan sebagai acuan dalam penyusunan penelitian. Berdasarkan penelitian yang dilakukan oleh (Sabil, 2017) dengan judul "Peranan Penerimaan Pajak Reklame Terhadap Pendapatan Asli Daerah Pada Kabupaten Bogor Jawa Barat" menjelaskan bahwa Potensi Pajak Reklame terhadap Pendapatan Asli Daerah tahun 2011, 2012, 2013, 2014, 2015 mengalami kenaikan serta melewati target yaitu rata-rata diatas $100 \%$. Pajak Reklame salah satu pajak yang berperan terhadap pendapatan asli daerah yang cukup berpengaruh. Pada tahun 2011, 2012, 2013, 2014, 2015, masing sebesar 1,449\%, 0,940\%, 0,971, 0,809\% , 0,688\%.

Penelitian yang di lakukan oleh (Gerald \& Wardhani, 2018) dengan judul "Analisis Laju Pertumbuhan Kontribusi Pajak Daerah dan Pengaruhnya terhadap Pendapatan Asli Daerah Kabupaten Bogor" menjelaskan bahwa kontribusi pajak daerah terhadap PAD Kabupaten Bogor selama tahun 2002 sampai dengan 2010 secara rata-rata selalu lebih besar dibandingkan dengan kontribusi dari sumber-sumber penerimaan Pendapatan Asli Daerah lainnya, yaitu sebesar $44,52 \%$ setiap tahunnya. Dan pada laju pertumbuhan kontribusi pajak daerah terhadap Pendapatan Asli Daerah kabupaten Bogor sebesar 3.344 yang diinterpretasikan sebagai rata-rata perkembangan atau peningkatan kontribusi pajak daerah tersebut adalah sebesar 3.344\% setiap tahunnya. Sedangkan penelitian yang di lakukan oleh (Triyono, 2018) dengan judul "Analisis Pengaruh Kontribusi Pajak Reklame Dan Pajak Hiburan Terhadap Pendapatan Asli Daerah (PAD) Pada Badan Pendapatan Daerah Kabupaten Indragiri Hulu" menjelaskan bahwa pada tahun 2013 hingga 2017, Pajak Reklame dan Pajak Hiburan di kabupaten Indragiri Hulu secara signifikan sangat kurang berkontribusi terhadap Pendapatan Asli Daerah (PAD).

Berdasarkan uraian diatas maka penulis tertarik untuk melakukan penelitian yang berkaitan dengan efektivitas dan kontribusi pajak daerah pada PAD. Peneliti tertarik melakukan penelitian ini karena ingin mengetahui apakah setelah tahun 2014 hingga lima tahun kedepan yaitu tahun 2015 sampai dengan tahun 2019 pendapatan pajak daerah pada sektor pajak reklame dan pajak restoran tetap stabil terus mengalami

Companies'Value and Tax

Avoidance Order 
Restaurant Tax, Advertising Tax \& Regional Revenue

\section{4}

peningkatan atau bahkan sebaliknya, lalu peneliti juga ingin menganalisis seberapa besar tingkat efektivitas dan kontribusi dari pajak reklame dan restoran terhadap PAD. Perbedaan antara penelitian terdahulu dengan penelitian ini adalah terdapat pada jenis pajak daerah yang diteliti dan tempat dilakukannya penelitian. Identifikasi Masalah

Berdasarkan uraian latar belakang diatas, maka rumusan masalah dalam penelitian ini adalah sebagai berikut : Bagaimana efektivitas penerimaan Pajak Reklame dan Pajak Restoran di Kota Bogor? Bagaimana kontribusi penerimaan Pajak Reklame dan Pajak Restoran terhadap PAD Kota Bogor? Serta Bagaimana upaya Badan Pendapatan Daerah Kota Bogor dalam meningkatkan pendapatan pajak reklame dan pajak restoran?

\section{METODE PENELITIAN}

Penelitian ini dilakukan di Kantor Badan Pendapatan Daerah Kota Bogor yang terletak di Jalan Pemuda No.31 Bogor 16161, Jawa Barat . Peneliti melakukan penelitian ini dimulai sejak tanggal 14 Juli - 31 Juli 2020. Jenis Penelitian yang digunakan dalam penelitian ini adalah metode kualitatif. Menurut Sugiyono (Jatsiyah,2018) mengatakan sebagai berikut: Metode kualitatif yaitu metode analisis yang bertujuan untuk mengembangkan teori yang telah dibangun dari data yang sudah didapatkan di lapangan. Metode ini pada tahap awalnya peneliti melakukan penjelajahan umum, dan menyeluruh kemudian dilakukan pengumpulan data sampai mendalam, mulai dari observasi hingga penyusunan laporan. Dalam penelitian ini juga menggunakan metode deskriptif. Menurut Nazir (Https://idtesis.com/metodedeskriptif) mengatakan sebagai berikut: Metode diskriptif adalah metode dalam meneliti status sekelompok manusia, suatu objek, suatu set kondisi suatu sistem pemikiran ataupun suatu kelas peristiwa pada masa sekarang. Tujuan dari penelitian deskriptif ini adalah untuk membuat depenelitian, gambaran atau lukisan secara sistematis, faktual dan akurat, mengenai fakta-fakta, sifat-sifat serta hubungan antara fenomena yang diselidiki.

Sumber Data yang digunakan oleh peneliti dalam penelitian ini yaitu menggunakan jenis data primer dan sekunder.Instrumen dalam pengumpulan data primer adalah dengan melakukan wawancara langsung dengan staff bagian pengelolaan pajak darah di kantor BAPENDA. Data sekunder yang diperoleh menggunakan studi literatur untuk memperoleh landasan teoritis dari masalah yang diteliti. Dokumen terkait yang digunakan dalam penelitian ini yaitu laporan tahunan PAD yang diambil langsung di kantor BAPENDA Kota Bogor khususnya laporan mengenai pajak reklame dan pajak restoran. Dalam melakukan penelitian ini, peneliti mendatangi kantor BAPENDA Kota Bogor dan melakukan aktivitas untuk mencari atau mengumpulkan data yang diperlukan. Variabel yang terdapat dalam penelitian ini adalah PAD, efektivitas dari pajak reklame dan pajak restoran, kontribusi dari pajak reklame dan pajak restoran serta upaya untuk meningkatkan penerimaan pajak reklame dan restoran. Dalam penelitian ini menggunakan metode analisis deskriptif pendeketan kualitatif. Metode analisis deskriptif kualitatif yaitu metode analisis yang bertujuan untuk mengembangkan teori yang telah dibangun dari data yang sudah didapatkan di lapangan. Metode ini pada tahap awalnya peneliti melakukan penjelajahan umum, dan menyeluruh kemudian dilakukan pengumpulan data sampai mendalam, mulai dari observasi hingga penyusunan laporan (Sugiyono, 2014:409) dalam penelitian (Jatsiyah, 2018).

\section{HASIL DAN PEMBAHASAN}

Hasil Penelitian

Pajak rek lame merupakan salah satu jenis pajak daerah. Perkembangan perekonomian Kota Bogor yang semakin meningkat setiap tahunnya berpotensi besar pada pendapatan pajak reklame.Berikut data penelitian mengenai target dan realisasi pajak reklame di Kota Bogor selama lima tahun yaitu dari tahun 2015 sampai tahun 2019. Data ini merupakan akumulasi dari beberapa objek reklame yang dipungut di Kota Bogor, diantaranya: reklame papan/bill board/videotron/megatron, reklame kain, reklame melekat/stiker, reklame berjalan, dan reklame udara. 
Tabel 4. Target dan Realisasi Pajak Reklame Kota Bogor

\begin{tabular}{|c|c|c|c|}
\hline Tahun & Target Pajak (Rp) & Realisasi Pajak (Rp) & Pencapaian (\%) \\
\hline 2015 & 12.000 .000 .000 & 12.486 .710 .087 & 4,06 \\
\hline 2016 & 13.000 .000 .000 & 13.069 .183 .675 & 0,53 \\
\hline 2017 & 10.300 .000 .000 & 10.907 .808 .067 & 5,90 \\
\hline 2018 & 10.500 .000 .000 & 10.926 .253 .439 & 4,06 \\
\hline 2019 & 11.000 .000 .000 & 11.708 .055 .331 & 6,44 \\
\hline \multicolumn{2}{|c|}{ Rata-rata } & 11.819 .602 .120 & 4,20 \\
\hline
\end{tabular}

Sumber: Kantor BAPENDA Kota Bogor, 2020

Berdasarkan tabel 4. diatas, target dan realisasi dari pajak reklame tahun 2015-2019 mengalami kenaikan dan penurunan di setiap tahunnya. Bahkan apabila dibandingkan dengan data target dan realisasi pajak di tahun 2014 seperti data di bab 1 ternyata nilai target dan realisasi pajak selama lima tahun berikutnya (Tahun 2015-2019) terus mengalami penurunan dan masih belum ada tanda tanda perubahan peningkatan yang mampu melebihi nilai target dan realisasi pajak seperti di tahun 2014. Meskipun mengalami kenaikan dan penurunan target pajak setiap tahunnya, namun pada nilai realisasi pajak selalu melebihi dari nilai target pajak. Pada tahun 2015 pencapaian realisasi pajak melebihi target pajak yaitu sebesar 4,06\%. Di tahun 2016 pencapaian realisasi pajak mengalami penurunan menjadi $0,53 \%$, namun pada nilai target pajak lebih besar dari tahun 2015 yaitu sebesar Rp13.000.000.000. Di tahun 2017 pencapaian realisasi pajak mengalami kenaikan menjadi 5,90\%, namun pada nilai target pajak mengalami penurunan yang disebabkan oleh salah satu objek pajak reklame yaitu Reklame Melekat/Stiker tidak dikenakan pungutan pajak. Pada tahun 2018 pencapaian realisasi pajak kembali mengalami penurunan menjadi 4,06\%. Di tahun 2019 pencapaian realisasi pajak kembali mengalami kenaikan menjadi $6,44 \%$ dan nilai target pajaknya juga mengalami kenaikan dari tahun sebelumnya yaitu sebesar Rp11.000.000.000, di tahun 2019 Reklame Melekat/Stiker sudah kembali dikenakan pungutan pajak.

Jiwa konsumtif masyarakat kota bogor yang cukup tinggi mempengaruhi para pengusaha saling bersaing untuk menciptakan suatu inovasi makanan/minuman yang menarik dan sesuai untuk selera masyarakat. Maka tidak dipungkiri, banyaknya pelaku usaha di bidang makanan dan minuman ikut serta meningkatkan jumlah tempat makan seperti, restoran, rumah makan, maupun cafe. Hal ini tentu berdampak positif bagi PAD khususnya dalam pemungutan pajak restoran. Berikut data penelitian mengenai target dan realisasi pajak restoran di Kota Bogor selama lima tahun yaitu dari tahun 2015 sampai tahun 2019. Data ini merupakan akumulasi dari beberapa objek pajak restoran yang dipungut di Kota Bogor, diantaranya: restoran, rumah makan, cafe, catering/jasa boga

Tabel 5 Target dan Realisasi Pajak Restoran Kota Bogor

\begin{tabular}{|l|c|c|c|}
\hline Tahun & Target Pajak (Rp) & Realisasi Pajak (Rp) & Pencapaian (\%) \\
\hline 2015 & 73.500 .000 .000 & 75.128 .975 .542 & 2.22 \\
\hline 2016 & 94.500 .000 .000 & 95.415 .220 .190 & 0.97 \\
\hline 2017 & 108.695 .260 .000 & 110.306 .908 .127 & 1.48 \\
\hline 2018 & 128.100 .000 .000 & 131.478 .976 .530 & 2.64 \\
\hline 2019 & 136.550 .494 .812 & 153.467 .175 .721 & 12.39 \\
\hline & Rata-rata & 113.159 .451 .222 & 3,94 \\
\hline
\end{tabular}

Sumber: Kantor BAPENDA Kota Bogor, 2020

Berdasarkan tabel 5, target dan realisasi dari pajak restoran tahun 2015-2019 terus mengalami kenaikan disetiap tahun. Jika dibandingkan pada lima tahun sebelumnya tahun 2010-2014 seperti data di bab 1, nilai target dan realisasi pajak restoran ternyata masih tetap konsisten terus mengalami kenaikan. Bahkan pada tahun 2019 dapat dikatakan pencapaian nilai realisasi pajak restoran yang paling tinggi dibandingkan tahun-tahun sebelumnya. Pada tahun 2015 pencapaian realisasi pajak melebihi nilai target pajak sebesar 2,22\%. Di tahun 2016, nilai pencapaian realisasi pajak mengalami penurunan menjadi sebesar $0,97 \%$ namun pada nilai target pajak mengalami kenaikan

Companies' Value and Tax Avoidance Order 
Restaurant Tax, Advertising Tax \& Regional Revenue

\section{6}

dari tahun 2015. Tahun 2017 pencapaian nilai realisasi pajak kembali mengalami kenaikan menjadi sebesar $1,48 \%$ begitu juga pada nilai target pajak kembali mengalami kenaikan yang cukup signifikan. Di tahun 2018 pencapaian nilai realisasi pajak masih tetap konsisten mengalami kenaikan menjadi sebesar 2,64\%, pada nilai target pajak juga mengalami kenaikan. Dan di tahun 2019 pencapaian nilai target pajak kembali mengalami kenaikan, dan dapat dikatakan kenaikannya cukup sangat signifikan yaitu sebesar $12,39 \%$, ini merupakan pencapaian realisasi pajak yang paling tinggi di bandingkan dengan tahun sebelumnya.

Pendapatan Asli Daerah (PAD) adalah semua penerimaan daerah yang berasal dari sumber ekonomi asli daerah. Berikut data realisasi pendapatan asli daerah Kota Bogor selama lima tahun yaitu dari tahun 2015 sampai tahun 2019.

Tabel 6. Target dan Realisasi PAD Kota Bogor

\begin{tabular}{|c|c|c|c|}
\hline Tahun & Target PAD (Rp) & Realisasi PAD (Rp) & Pencapaian (\%) \\
\hline 2015 & 627.815 .080 .243 & 627.594 .065 .141 & - \\
\hline 2016 & 728.030 .823 .933 & 783.873 .586 .219 & $1,07 \%$ \\
\hline 2017 & 917.788 .606 .450 & 978.197 .741 .947 & $1,06 \%$ \\
\hline 2018 & 887.396 .041 .682 & 912.197 .971 .288 & $1,03 \%$ \\
\hline 2019 & 972.607 .288 .978 & 1.012 .529 .573 .960 & $1,04 \%$ \\
\hline
\end{tabular}

Sumber: Kantor BAPENDA Kota Bogor, 2020

Tabel 6 diatas menunjukan bahwa target dan realisasi dari pendapatan asli daerah Kota Bogor selama lima tahun dari tahun 2015 sampai tahun 2019 hampir selalu mengalami peningkatan setiap tahunnya. Hanya saja pada tahun 2015 pencapaian realisasi masih belum mencapai target yang di tentukan dan di tahun 2018 nilai target PAD mengalami penurunan sebesar Rp30.392.564.768 disebabkan adanya penurunan dari jenis pendapatan PAD yang lain seperti retribusi daerah, kekayaan daerah, dan lain-alin pendapatan PAD yang sah. Namun meskipun mengalami penurunan target tetapi untuk hasil realisasi PAD yang dicapai di tahun 2018 cukup signifikan yaitu sebesar $1,03 \%$. Jika dibandingkan dengan realisasi PAD pada lima tahun sebelumnya tahun 2010-2014 seperti data di bab 1, PAD di kota bogor dapat dikatakan sudah cukup baik dengan membuktikannya pada nilai target dan pencapaian nilai realisasi PAD yang hamir terus mengalami kenaikan setiap tahunnya.

\section{Upaya-Upaya Meningkatkan Pajak Reklame danPajak Restoran}

Pencapaian target dan realisasi pajak tidak lepas dari peran aktif para petugas dalam melakukan pemungutan pajak dan rencana-rencana kerja yang di buat oleh pemerintah dalam mengupayakan agar pencapaian nilai target- taraget pajak dapat terus terrealisasi secara optimal dan meningkat. Berdasarkan hasil wawancara yang dilakukan secara langsung dengan staf bagian pengelolaan pajak daerah di kantor BAPENDA mengenai upaya dalam meningkatkan pajak reklame dan pajak restoran bagi pendapatan daerah di Kota Bogor, maka dapat dideskripsikan sebagai berikut:

1. Melaksanakan Pendataan Wajib Pajak. Untuk mendapatkan data wajib pajak reklame dan pajak restoran, haruslah dilaksanakan pendaftaran dan pendataan wajib pajak baik yang berdomisili di dalam maupun di luar wilayah kota Bogor. Langkah-langkah yang dilakukan oleh Badan Pendapatan Daerah Kota Bogor dalam rangka pendaftaran dan pendataan wajib pajak adalah dengan cara menerbitkan Surat Pemberitahuan Pajak Daerah (SPTPD) yang digunakan oleh wajib pajak untuk melaporkan perhitungan dan pembayaran pajak. Sebelum menertibkan SPTPD, petugas lapangan dari Badan Pendapatan Daerah Kota Bogor terlebih dahulu melakukan pendataan terhadap wajib pajak dengan melakukan survey lapangan, pemantauan dan pemeriksaan. Setelah melakukan survey, pemantauan dan pemeriksaan Badan Pendapatan Daerah kemudian mengeluarkan/memberikan surat resmi kepada wajib pajak perihal kegiatan pendataan objek pajak yang berisikan keterangan batas waktu untuk segera melakukan pendaftaran pajak, biasanya batas waktu yang ditentukan adalah maksimal 30 hari setelah diterbitkan SPTPD kepada wajib pajak. Apabila dalam 30 
hari masih belum melakukan pendaftaran pajak, maka Bapenda Kota Bogor akan menertibkan surat peringatan pertama serta diberikan surat undangan ke Bapenda agar wajib pajak mengetahui hasil analisa pendataan. Pemeriksaan terhadap wajib pajak dimaksudkan untuk menguji sekaligus meningkatkan kesadaran pemenuhan kewajiban perpajakan. Diharapkan melalui kegiatan survey lapangan, pemantauan dan pemeriksaan pajak para wajib pajak akan sadar akan kewajibannya untuk membayarpajak.

2. Pemeriksaan Tarif Pajak. Besaran tarif pajak reklame dan restoran telah ditetapkan sesuai dengan peraturan daerah kota bogor sebesar $10 \%$ untuk pajak restoran dan $25 \%$ untuk pajak reklame. Petugas pajak melakukan pemeriksaan tarif pajak dengan melakukan observasi langsung ke lapangan. Observasi lapangan bertujuan untuk penghitungan kasar atas penilaian kebenaran pajak yang sudah dibayar atau pajak yang akan dibayar oleh wajib pajak, apakah jumlahnya sesuai atau masih jauh dari jumlah yang seharusnya dibayarkan. Pemeriksaan pajak dilakukan dengan dua cara yaitu dengan official assessment dan self assessment. Official assessment merupakan sistem pemungutan pajak yang memberikan kewenangan kepada pihak ketiga untuk menetapkan besaran pajak yang terhutang (Pajak reklame). Self assessment adalah sistem pemungutan pajak yang memberikan kepercayaan kepada wajib pajak untuk menentukan sendiri besaran pajak yang terhutang (Pajak restoran). Pemeriksaan tarif pajak dimaksudkan untuk meningkatkan kesadaran dan kejujuran para wajib pajak dalam melakukan pembayaran besaran pajak yang terhutang dan tujuan lainnya adalah agar para wajib pajak dapat membayar tepat waktu dan tepat jumlah sehingga dapat meningkatkan kontribusi pajak reklame dan pajak restoran terhadap PAD secara efektif dan signifikan.

3. Pengawasan Penyelenggaraan Pajak. Pengawasan dalam penyelenggaraan pajak dilakukan untuk menciptakan ketertiban dalam pemungutan dan penyelenggaraan pajak. Proses yang dilakukan untuk meningkatkan pajak reklame yaitu dengan melakukan penataan titik/zona pemasangan reklame dan melakukan pemberian sanksi secara tegas kepada wajib pajak yang melanggar aturan, sanksi tersebut adalah berupa pembongkaran reklame. Sedangkan untuk meningkatkan pajak restoran dilakukan dengan penerapan online sistem pelaporan data transaksi usaha untuk wajib pajak restoran dimana setiap transaksi yang dilakukan terhubung secara real team pada sistem BAPENDA. Sehingga setiap akhir bulan dapat diketahui berapa jumlah transaksi dan pajak yang harus disetorkan oleh wajib pajak tersebut. Dalam penerapan online sistem telah dilakukan pemasangan alat berupa tapping box pada wajib pajak. Tapping box yang sudah terpasang di Koto Bogor sekitar 200 tapping box.

4. Membangun Komunikasi dan Menjalin Kedekatan Dengan Masyarakat Petugas pajak merupakan mata rantai komunikasi antara pemerintah dengan masyarakat. Peran aktif dalam proses komunikasi dan pelaksanaan akan membawa kedekatan tersendiri dengan masyarakat. Kedekatan ini yang pada akhirnya dapat menimbulkan rasa simpati dan menghasilkan rasa kepercayaan masyarakat khususnya wajib pajak. Hal ini tentu akan berpengaruh dan bermanfaat pada pembayaran pajak di Kota Bogor. Dalam proses menjalin kedekatan dengan masyarakat para petugas pajak melakukan sosialisasi secara berkala. Sosialisasi dilakukan dengan tujuan agar wajib pajak/masyarakat dapat mengetahui peraturan perpajakan dan untukmenarik kesadaran wajib pajak untuk membayar pajak.

\section{Pembahasan}

Pendapatan Asli Daerah merupakan sumber pendapatan terbesar bagi daerah. Dilihat dari tingginya realisasi penerimaan pajak daerah yang merupakan sumber pendapatan asli daerah. Pendapatan Asli Daerah seringkali dijadikan sebagai indikator atas kemajuan suatu daerah. Apabila pendapatan asli suatu daerah tinggi maka bisa dikatakan bahwa daerah tersebut sudah dianggap maju. Semakin tinggi Pendapatan Asli Daerah yang diterima maka semakin berkurang tingkat ketergantungan antara Pemerintah Daerah terhadap Pemerintah Pusat. Kota Bogor merupakan kota yang
Companies' Value and Tax

Avoidance Order 
Restaurant Tax, Advertising Tax \& Regional Revenue

88 pertumbuhan dan perkembangan perekonomiannya relatif cepat. Pemerintah Kota Bogor terus berupaya untuk meningkatkan sumber-sumber pendapatan asli daerahnya. Yang mana sumber tersebut adalah berasal dari pajak daerah. Pemerintah Kota Bogor memungut 9 (sembilan) pajak daerah, yaitu: pajak hotel, pajak restoran, pajak hiburan, pajak reklame, pajak penerangan jalan, pajak parkir, pajak air bawah tanah, pajak bumi dan pembangunan perkotaan, dan pajak bea perolehan hak atas tanah dan bangunan. Badan Pendapatan Daerah (BAPENDA) Kota Bogor merupakan badan yang melaksanakan berbagai urusan dibidang pendapatan daerah. Adapun fungsinya adalah membuat atau merumuskan kebijakan teknis dibidang pendapatan daerah, menyelenggarakan urusan pemerintah dan pelayanan umum dibidang pendapatan daerah, melakukan pembinaan dan pelaksanaan tugas dibidang pendapatan daerah, serta melaksanakan tugas lain yang ditugaskan oleh walikota sesuai tugas dan fungsinya. Badan Pendapatan Daerah Kota Bogor menggunakan sistem self assessment dan official assessment dalam pemungutan pajak daerahnya, dan untuk pajak reklame sistem pemungutannya menggunakan sistem official assessment sedangkan untuk pajak restoran sistem pemungutannya menggunakan sistem self assessment. Upaya yang dilakukan oleh BAPENDA Kota Bogor dalam meningkatkan atau memenuhi target pajak reklame dan pajak restoran adalah dengan melakukan pendataan wajib pajak, pemeriksaan tarif pajak, pengawasan penyelenggaraan pajak, membangun komunikasi dan menjalin kedekatan dengan masyarakat, dengan tujuan dari upaya-upaya tersebut adalah untuk meningkatkan kesadaran dan pengetahuan pajak yang dimiliki masyarakat mengenai pentingnya membayar pajak, serta uapaya lain yang dilakukan adalah peran aktif para petugas pajak di lapangan. Adapun sanksi yang diberikan kepada wajib pajak yang melakukan kesalahan atau penunggakan pembayaran pajak restoran dan reklame akan dikenakan berupa sanksi administrasi, dan sanksi tegas berupa pembongkaran reklame bagi para wajib pajak yang melanggar aturan pemasangan reklame.

\section{Analisis Efektivitas Penerimaan Pajak Reklame dan Pajak Restoran Kota Bogor}

Rasio efektivitas menggambarkan kemampuan pemerintah daerah dalam merealisasikan pendapatan asli daerah yang direncanakan dibandingkan dengan target yang ditetapkan berdasarkan potensi riil daerah. Apabila perhitungan efektivitas pajak reklame menghasilkan angka atau presentase mendekati atau sampai melebihi $100 \%$, maka pajak reklame semakin efektif atau dengan kata lain kinerja pemerintah dalam melakukan pemungutan pajak reklame dan pajak restoran di Kota Bogor semakin baik. Dibawah ini adalah tabel kriteria perhitungan rasio efektivitas :

Tabel 7. Tingkat Mengukur Efektivitas

\begin{tabular}{|c|c|}
\hline Presentase & Kriteria \\
\hline$>100 \%$ & Sangat Efektif \\
\hline $80 \%-100 \%$ & Efektif \\
\hline $60 \%-80 \%$ & Kurang Efektif \\
\hline $40 \%-60 \%$ & Tidak Efektif \\
\hline
\end{tabular}

Sumber: di kutip dari (Oktavia, 2018)

Tingkat efektivitas pajak restoran dihitung dengan membandingkan realisasi penerimaan pajak restoran dengan target pajak restoran yang ditetapkan. Dibawah ini disajikan hasil perhitungan untuk melihat kriteria dan rasio efektivitas penerimaan pajak restoran selama lima tahun di Kota Bogor. Tabel 8 menunjukan bahwa rasio efektivitas penerimaan pajak restoran di Kota Bogor selama lima tahun hampir selalu mengalami kenaikan. Meskipun di tahun 2016 presentase rasio efektivitas pajak restoran mengalami penurunan, tetapi itu tidak mempengaruhi tingkat kriteria efektivitas pajaknya yaitu mencapai 100,97\% yang berarti masih sangat efektif. Melihat tabel tersebut, secara keseluruhan hasil presentase rasio efektivitas pajak restoran pada angka rata-rata mencapai 103,93\% maka dapat disimpulkan bahwa efektivitas pajak restoran di Kota Bogor sangat efektif. Dan ini juga menunjukan bahwa kinerja pemerintah bogor dalam melakukan pemungutan pajak restoransudah sangat baik. 
Tabel 8. Rasio dan Kriteria Efektivitas Penerimaan Pajak Restoran di Kota Bogor

\begin{tabular}{|c|c|c|c|c|}
\hline Tahun & $\begin{array}{l}\text { Target Pajak } \\
\text { (Rp) }\end{array}$ & $\begin{array}{l}\text { Realisasi Pajak } \\
\text { (Rp) }\end{array}$ & $\begin{array}{c}\text { Rasio } \\
\text { Efektivitas (\%) }\end{array}$ & Kriteria \\
\hline 2015 & 73.500 .000 .000 & 75.128 .975 .542 & 102,22 & Sangat Efektif \\
\hline 2016 & 94.500 .000 .000 & 95.415 .220 .190 & 100,97 & Sangat Efektif \\
\hline 2017 & 108.695 .260 .000 & 110.306 .908 .127 & 101,48 & Sangat Efektif \\
\hline 2018 & 128.100 .000 .000 & 131.478 .976 .530 & 102,64 & Sangat Efektif \\
\hline 2019 & 136.550 .494 .812 & 153.467 .175 .721 & 112,39 & Sangat Efektif \\
\hline \multicolumn{3}{|c|}{ rata } & 103,93 & Sangat Efektif \\
\hline
\end{tabular}

Companies' Value and Tax Avoidance Order

Sumber: (Data Diolah, 2020)

Hasil Analisis Efektivitas Pajak Reklame

Tingkat penerimaan pajak reklame sangat erat kaitannya dengan banyaknya jumlah media reklame yang terpasang. Semakin tinggi jumlah media reklame yang terpasang maka semakin tinggi pula realisasi pemungutan pajak reklame. Pajak reklame juga merupakan salah satu jenis pajak yang di pengaruhi oleh perkembangan jumlah usaha kuliner seperti restoran, cafe dan tempat makan lainnya. Semakin banyak jumlah usaha kuliner baru yang didirikan maka semakin besar jumlah realisasi dari pajak reklame. Berikut adalah tabel hasil perhitungan untuk melihat kriteria dan rasio efektivitas penerimaan pajak reklame selama lima tahun di Kota Bogor.

Tabel 9 Rasio dan Kriteria Efektivitas Penerimaan Pajak Reklame di Kota Bogor

\begin{tabular}{|c|c|c|c|c|}
\hline Tahun & $\begin{array}{l}\text { Target Pajak } \\
(\mathrm{Rp})\end{array}$ & $\begin{array}{l}\text { Realisasi Pajak } \\
\text { (Rp) }\end{array}$ & $\begin{array}{c}\text { Rasio } \\
\text { Efektivitas (\%) }\end{array}$ & Kriteria \\
\hline 2015 & 12.000 .000 .000 & 12.486 .710 .087 & 104,06 & Sangat Efektif \\
\hline 2016 & 13.000 .000 .000 & 13.069 .183 .675 & 100,53 & Sangat Efektif \\
\hline 2017 & 10.300 .000 .000 & 10.907 .808 .067 & 105,90 & Sangat Efektif \\
\hline 2018 & 10.500 .000 .000 & 10.926 .253 .439 & 104,06 & Sangat Efektif \\
\hline 2019 & 11.000 .000 .000 & 11.708 .055 .331 & 106,44 & Sangat Efektif \\
\hline \multicolumn{3}{|c|}{ Rata-rata } & 104,20 & Sangat Efektif \\
\hline
\end{tabular}

Sumber: (Data Diolah, 2020)

Tabel 9 diatas menunjukan bahwa rasio efektivitas penerimaan pajak reklame di Kota Bogor selama lima tahun berfluktuatif, namun untuk kriteria efektivitas dapat dikatakan sangat efektif semua karena angka rasio efektivitas di setiap tahun mampu melebihi $100 \%$ atau melebihi target yang telah ditentukan. Pada angka rata-rata rasio efektivitas pun juga sama melebihi $100 \%$ yaitu sebesar 104,20\%, maka dapat di simpulkan bahwa efektivitas penerimaan pajak reklame selama lima tahun terhitung dari tahun 2015 sampai tahun 2019 di Kota Bogor termasuk kedalam kriteria sangat efektif. Dan ini juga menunjukan bahwa kinerja pemerintah bogor dalam melakukan pemungutan pajak reklame sudah baik.

\section{Analisis Kontribusi Penerimaan Pajak Reklame dan Pajak Restoran Terhadap PAD Kota Bogor}

Kontribusi digunakan untuk mengetahui sejauh mana pajak reklame dan pajak restoran memberikan sumbangan dalam penerimaan PAD. Pendapatan asli daerah merupakan modal dalam bentuk dana bagi setiap daerah untuk memajukan dan menyejahterakan masyarakat didaerahnya. Dalam mengetahui kontribusi dilakukan dengan membandingkan penerimaan pajak daerah (khususnya pajak reklame dan pajak restoran) dengan penerimaan PAD. Apabila perhitungan kontribusi pajak reklame dan restoran menghasilkan angka atau presentase mendekati atau melebihi 50\%, maka kontribusi pajak reklame dan restoran semakin efektif atau dengan kata lain kinerja pemungutan pajak reklame Kota Bogor semakin baik.

\section{Hasil Analisis Kontribusi Pajak Restoran Terhadap PAD}

Pajak restoran merupakan salah satu pajak daerah yang berkontribusi cukup besar untuk meningkatkan pendapatan asli daerah Kota Bogor. Besaran kontribusi pajak restoran terhadap pendapatan asli daerah dapat dilihat pada tabel hasil perhitungan dibwah ini. 
Restaurant Tax, Advertising Tax \& Regional Revenue

90
Tabel 10. Tingkat Mengukur Kontribusi

\begin{tabular}{|c|c|}
\hline Presentase & Kriteria \\
\hline$>50 \%$ & Sangat Baik \\
\hline $40 \%-50 \%$ & Baik \\
\hline $30 \%-40 \%$ & Cukup Baik \\
\hline $20 \%-30 \%$ & Sedang \\
\hline $10 \%-20 \%$ & Kurang \\
\hline$<10 \%$ & Sangat Kurang \\
\hline
\end{tabular}

Sumber: di kutip dari (Oktavia, 2018)

Tabel 11 Rasio dan Kriteria Kontribusi Penerimaan Pajak Restoran Terhadap PAD

\begin{tabular}{|c|c|c|c|c|}
\hline Tahun & Realisasi PAD (Rp) & $\begin{array}{l}\text { Realisasi Pajak } \\
\text { Reklame (Rp) }\end{array}$ & $\begin{array}{c}\text { Rasio Kontribusi } \\
(\%)\end{array}$ & Kriteria \\
\hline 2015 & 627.594 .065 .141 & 75.128 .975 .542 & 11,97 & Kurang \\
\hline 2016 & 783.873.587.219 & 95.415 .220 .190 & 12,17 & Kurang \\
\hline 2017 & 978.197 .741 .947 & 110.306 .908 .127 & 11,28 & Kurang \\
\hline 2018 & 912.197.971.288 & 131.478 .976 .530 & 14,41 & Kurang \\
\hline 2019 & 1.012 .529 .573 .960 & 153.467 .175 .721 & 15,16 & Kurang \\
\hline \multicolumn{3}{|c|}{ Rata-Rata } & 12,99 & Kurang \\
\hline
\end{tabular}

Sumber: ( Data Diolah, 2020)

Dari tabel 11 diatas, dapat dilihat angka rasio kontribusi pajak restoran secara garis besar terus mengalami kenaikan. Hanya saja di tahun 2017 rasio kontribusi pajak restoran mengalami penurunan yang diakibatkan adanya penerimaan kontribusi dari jenis pajak daerah yang lain meningkat yaitu pada pajak bea perolehan hak atas tanah dan bangunan, pajak parir, pajak penerangan jalan, pajak hiburan dan pajak hotel. Jika di lihat pada angka rasio kontribusi pajak restoran di setiap tahunnya yaitu tahun 2015 sebesar 11,97\%, tahun 2016 sebesar 12,17\%, tahun 2017 sebesar 11,28\%, tahun 2018 sebesar 14,41\%, tahun 2019 sebesar 15,16\% sehingga angka rata-rata yang di peroleh sebesar $12,99 \%$, maka dapat di simpulkan bahwa kontribusi pajak restoran terhadap pendapatan asli daerah Kota Bogor termasuk ke dalam kriteria kurang.

\section{Hasil Analisis Kontribusi Pajak Reklame Terhadap PAD}

Pajak reklame merupakan salah satu dari pajak daerah yang memiliki realisasi pajak yang tinggi dari nilai targetnya, semakin tinggi realisasi pajak reklame maka semakin besar kontribusinya pada pendpatan asli daerah. Untuk melihat seberapa besar kontribusi penerimaan pajak reklame terhadap pendapatan asli daerah di Kota Bogor, dapat dilihat pada tabel hasil perhitungan dibwah ini.

Tabel 12 Rasio dan Kriteria Kontribusi Penerimaan Pajak Reklame Terhadap PAD

\begin{tabular}{|c|c|c|c|c|}
\hline Tahun & Realisasi PAD (Rp) & $\begin{array}{c}\text { Realisasi Pajak } \\
\text { Reklame (Rp) }\end{array}$ & \begin{tabular}{|c|} 
Rasio \\
Kontribusi (\%) \\
\end{tabular} & Kriteria \\
\hline 2015 & 627.594 .065 .141 & 12.486 .710 .087 & 1,99 & Sangat Kurang \\
\hline 2016 & 783.873.587.219 & 13.069 .183 .675 & 1,67 & Sangat Kurang \\
\hline 2017 & 978.197 .741 .947 & 10.907 .808 .067 & 1,12 & Sangat Kurang \\
\hline 2018 & 912.197.971.288 & 10.926 .253 .439 & 1,20 & Sangat Kurang \\
\hline 2019 & 1.012 .529 .573 .960 & 11.708 .055 .331 & 1,16 & Sangat Kurang \\
\hline \multicolumn{3}{|c|}{ Rata-Rata } & 1,43 & Sangat Kurang \\
\hline
\end{tabular}

Sumber: ( Data Diolah, 2020)

Dari tabel 12 diatas menunjukan bahwa rasio kontribusi dari pajak reklame terhadap pendapatan asli daerah Kota Bogor selama lima tahun terhitung dari tahun 2015 sampai dengan tahun 2019 terus mengalami penurunan di setiap tahunnya, yang diakibatkan adanya penerimaan kontribusi dari jenis pajak daerah yang lain meningkat yaitu pada pajak bea perolehan hak atas tanah dan bangunan, Pajak bumi dan pembangunan perkotaan, pajak parir, pajak penerangan jalan, pajak hiburan dan pajak hotel, dan pajak restoran. Dilihat pada angka rasio kontribusi pajak reklame di setiap tahunnya yaitu tahun 2015 sebesar $1,99 \%$, tahun 2016 sebesar 1,67\%, tahun 2017 sebesar 1,12\%, tahun 2018 sebesar 1,20\%, tahun 2019 sebesar 1,16\% sehingga angka 
rata-rata yang di peroleh sebesar $1,43 \%$, maka dapat di simpulkan bahwa kontribusi pajak reklame terhadap pendapatan asli daerah Kota Bogor termasuk ke dalam kriteria sangat kurang.

\section{PENUTUP}

Berdasarkan hasil Analisis Efektivitas dan Kontribusi Pajak Reklame dan Pajak Restoran Terhadap Pendapatan Asli Daerah di Kota Bogor Tahun 2015- 2019, maka dapat disimpulkan:

1. Efektivitas penerimaan Pajak Reklame dan Pajak Restoran di Kota Bogor sudah sangat efektif terbukti dengan angka rata-rata rasio efektivitas pajak reklame sebesar $104,06 \%$ dan pajak restoran sebesar $103,93 \%$. Ini juga menunjukan bahwa kinerja pemerintah bogor dalam melakukan pemungutan pajak reklame dan pajak restoran sudah baik.

2. Kontribusi pajak reklame dan pajak restoran terhadap PAD di Kota Bogor masih belum dapat dikatakan baik, dibuktikan dengan angka rata-rata rasio kontribusi pajak reklame sebesar $1,43 \%$ termasuk kriteria sangat kurang, dan rata-rata kontribusi pajak restoran sebesar 12,99\% termasuk kedalam kriteria kurang.

3. Upaya yang dilakukan oleh Badan Pendapatan Daerah Kota Bogor dalam meningkatkan pendapatan pajak reklame dan pajak restoran adalah dengan melakukan pendataan wajib pajak, pemeriksaan tarif pajak, pengawasan penyelenggaraan pajak, dan membangun komunikasi dan menjalin kedekatan dengan masyarakat.

\section{DAFTAR PUSTAKA}

Gerald, S., \& Wardhani, Y. (2018). Analisis Laju Pertumbuhan Kontribusi Pajak Daerah dan Pengaruhnya terhadap Pendapatan Asli Daerah Kabupaten Bogor. 2(2), 90-117.

Handayani, M. (2019). Pendapatan Asli Daerah (A. Pratomo, ed.). Poliban Press.

Hebimisa, M. T., Sondakh, J. J., \& Wangkar, A. (2017). Analisis Efektivitas Dan Kontribusi Penerimaan Pajak Reklame, Pajak Bumi Dan Bangunan Terhadap Pendapatan Asli Daerah Kabupaten Siau Tagulandang Biaro. Going Concern : Jurnal Riset Akuntansi, 12(2), 1021-1032.

Jatsiyah, nabilla. (2018). Pengaruh Kontribusi Pajak Bumi dan Bangunan Terhadap PAD di Kabupaten Bogor.

Lamia, A. A., Saerang, D. P. E., \& Wokas, H. R. . (2015). Analisis Efektifitas Dan Kontribusi Pemungutan Pajak Restoran, Pajak Reklame, Dan Pajak Penerangan Jalan Pada Pendapatan Asli Daerah Kabupaten Minahasa Utara. Jurnal Berkala Ilmiah Efisiensi, 15(05), 788-799.

Mardiasmo. (2016). Definisi dan unsur pajak (Perpajakan). ANDI - Yogyakarta. Oktavia, D. (2018). Analisis Efektivitas Dan Kontribusi Pemungutan Pajak Reklame Terhadap Pendapatan Asli Daerah Di Kota Bukit Tinggi.

Peraturan Daerah. Peraturan Daerah Nomor 6 Tahun 1990 tanggal 10 Agustus 1990 dibentuk Struktur Organisasi Badan Pendapatan Daerah. , (1990).

Peraturan daerah kota bogor. Peraturan Daerah Kota Bogor Nomor 21 Tahun 2011 tentang Ketentuan Umum Pajak Daerah. , 2 Pemerintah wali kota bogor (2011).

Peraturan daerah kota bogor. Tahun 2011 Nomor 3 Seri B Peraturan Daerah Kota Bogor Nomor 4 Tahun 2011 Tentang Pajak Reklame. , (2011).

Peraturan Daerah Kota Bogor. Peraturan Daerah Kota Bogor Nomor 13 Tahun 2008 tanggal 26 Desember 2008 tentang Organisasi Perangkat Daerah Kota Bogor. , (2008).

Peraturan Daerah Kota Bogor. Peraturan Daerah Kota Bogor Nomor 3 Tahun 2010 tanggal 24 Agustus 2010 tentang Organisasi Perangkat Daerah. , (2010).

Peraturan Daerah Kota Bogor. (2011). Pajak Restoran (pp. 1-30).

Peraturan Daerah Kotamadya Bogor. Peraturan Daerah Kotamadya Bogor Nomor 2 tahun 1979 tentang Susunan Organisasi Tata Kerja Badan Pendapatan Daerah Kotamadya DT.II Bogor. , (1979).
Companies'Value and Tax

Avoidance Order 
Restaurant Tax, Advertising Tax \& Regional Revenue

92
Peraturan perundang-undangan otonomi daerah. Undang-Undang Nomor 32 Tahun 2004 tentang Otonomi Daerah. , (2004).

Peraturan perundang-undangan PAD. Undang-undang nomor 33 pasal 1 ayat 15 tahun 2004. , (2004).

Peraturan wali kota bogor. Peraturan Wali Kota Bogor nomor 60 tahun 2018 tentang perizinan Penyelenggaraan Reklame. , (2018).

Purba, R., \& Ginting, R. M. H. (2016). Pengaruh Penerimaan Pajak Reklame dan Pajak penerangan Jalan terhadap Pendapatan Asli Daerah. Jurnal Mutiara Akuntansi, $1(1), 25-31$.

Republika.co.id. (2020). Bogor Tata Ulang Lokasi Pemasangan Reklame. from Ani Nursalikah website: https://republika.co.id/berita/q3wc86366/bogor- tata-ulanglokasi-pemasangan-reklame

Sabil. (2017). Peranan Penerimaan Pajak Reklame Terhadap Pendapatan Asli Daerah. Moneter - Jurnal Akuntansi Dan Keuangan, 4(2), 145-149. from http://ejournal.bsi.ac.id/ejurnal/index.php/moneter/article/view/2230/17 03

Sidik. (2002). Upaya Meningkatkan Pendapatan Daerah. Sugiyono. (2017). Data Primer.

Sugiyono. (2017). Data Sekunder.

Triyono, A. (2018). Analisis Pengaruh Kontribusi Pajak Reklame dan Pajak Hiburan Terhadap PAD Pada Badan Pendapatan Daerah Kabupaten Indragiri Hulu. VII(03), 63-75.

Undang-undang Pajak Daerah dan Retribusi Daerah. Undang-undang Pajak Daerah dan Retribusi Daerah Nomor 28 Tahun 2009. , (2009).

Wijayanti, R., Shodiq Askandar, N., \& Amin, M. (2017). Analisis Efektivitas dan Kontribusi Pajak Reklame Terhadap PAD di Kota Malang (Studi Kasus di Badan Pelayanan Pajak Daerah (BP2D) Kota Malang). Boswer 20007, 14- 27. 